\title{
Mental health status of health-care professionals working in quarantine and non-quarantine Egyptian hospitals during the COVID-19 pandemic
}

\author{
Naglaa Youssef, ${ }^{1}$ Aya Mostafa, ${ }^{2}$ Reem Ezzat, ${ }^{3}$ Mostafa Yosef $^{2}$ and Mohamed El Kassas ${ }^{4}$
}

${ }^{1}$ Medical-Surgical Nursing Department, Faculty of Nursing, Cairo University, Cairo, Egypt. ${ }^{2}$ Department of Community, Environmental, and Occupational Medicine, Faculty of Medicine, Ain Shams University, Cairo, Egypt. ${ }^{3}$ Internal Medicine Department, Faculty of Medicine, Assiut University, Assiut, Egypt. ${ }^{E}$ Endemic Medicine Department, Faculty of Medicine, Helwan University, Cairo, Egypt. (Correspondence to: Mohamed El Kassas: m_elkassas@hq.helwan.edu.eg)

\begin{abstract}
Background: Variable models of care have been adopted in different countries in response to the COVID-19 pandemic. Egypt has assigned certain hospitals specifically for the quarantine of COVID-19 patients, where operational medical teams work continuously for 14 days, after which they are released for self-isolation at home for a similar period.

Aims: The study aimed to evaluate and compare perceived adverse psychological symptoms (stress, anxiety, depression), and insomnia by health-care professionals working in quarantine and non-quarantine hospitals during the COVID-19 pandemic in Egypt, and to explore associated factors with adverse psychological symptoms and insomnia.

Methods: An online cross-sectional survey was performed in April 2020, using a snowball sampling method. Sociodemographic information perceived general health, healthy lifestyle, insomnia (using Insomnia Severity Index), adverse psychological symptoms (using the Depression, Anxiety and Stress Scale-21), worries and concerns about COVID-19, future perspective about COVID-19, and coping strategies were collected.

Results: Five hundred and forty health-care professionals participated; $10.2 \%(n=55)$ worked in quarantine hospitals. Younger age ( $\mathrm{ORa}=0.96,95 \% \mathrm{CI}: 0.93-0.99, \mathrm{ORa}=0.95 ; 95 \% \mathrm{CI}: 0.92-0.97 ; \mathrm{ORa}=0.96 \mathrm{CI}: 0.93-0.99)$, being not ready/sure of readiness to work in quarantine hospital (ORa $=1.91$, 95\% CI:1.22-3.00; ORa $=2.01,95 \%$ CI:1.28-3.15; ORa=1.91, 95\% CI:1.222.98), and insomnia (ORa=5.22, 95\% CI:3.38-8.05; ORa=7.58, 95\% CI:4.91-11.68; ORa=6.38 95\% CI:4.19-9.73) significantly predicted stress, depression and anxiety, respectively. Being female (ORa=1.59, 95\% CI:1.04-2.42; ORa=2.09, 95\% CI:1.383.16) could also significantly predict stress and anxiety.

Conclusion: Female and younger age health care professionals were more prone to report adverse psychological symptoms. More and earlier screening for health-care professionals dealing with COVID-19, in addition to providing psychological support, is highly encouraged.

Keywords: COVID-19, pandemic, Egypt, mental health, psychological distress

Citation: Youssef N; Mostafa A; Ezzat R; Yosef M; El Kassas M. Mental health status of health-care professionals working in quarantine and non-quarantine Egyptian hospitals during the COVID-19 pandemic. East Mediterr Health J. 2020;26(10):1155-1164. https://doi.org/10.26719/emhj.20.116 Received: 14/06/20; accepted: 31/08/20

Copyright $($ C World Health Organization (WHO) 2020. Open Access. Some rights reserved. This work is available under the CC BY-NC-SA 3.0 IGO license (https://creativecommons.org/licenses/by-nc-sa/3.o/igo)
\end{abstract}

\section{Introduction}

The novel SARS-CoV-2, known to cause coronavirus disease 2019 (COVID-19), emerged in Wuhan, China, and spread rapidly to every continent $(1,2)$. SARS-CoV-2 is very contagious and has an efficient person-to-person transmission, which could be more evident in health-care settings (2). On 11 March 2020, COVID-19 was reported as a global pandemic; in the Eastern Mediterranean Region more than 17 out of 22 countries had reported infected cases $(3,4)$.

The pandemic has been a source of numerous stressors on health-care professionals who have been found to display heightened stress, become emotionally affected and traumatized, and have higher levels of depression and anxiety (5-7). Moreover, health-care professionals are vulnerable to post-traumatic stress disorders, which may develop following exposure to traumatic events among workers operating in such a pandemic context $(8,9)$. One of the major global health challenges has been to protect health-care professionals and prevent the health-care system from being overwhelmed.

As a response to the COVID-19 epidemic, Egypt established a unique care model under World Health Organization (WHO) supervision, whereby specific hospitals are assigned as "quarantine hospitals" for COVID-19 patients. Operational medical teams reside in the hospital for 14 days continuously. Following a negative test for SARS-CoV-2, health-care professionals are then released for self-isolation at home for another 14 days. Positive-swab doctors (if any), are admitted to the same quarantine hospital to receive medical care.

This study aimed to evaluate and compare perceived adverse psychological symptoms (i.e., stress, anxiety, depression) and insomnia severity demonstrated by health-care professionals working in quarantine and non-quarantine hospitals during the COVID-19 pandemic 
in Egypt, and to explore associated factors with such psychological symptoms and insomnia.

\section{Methods}

\section{Study design, settings and participants}

This cross-sectional online survey study was conducted in Egypt during April 2020 using an anonymous questionnaire. The survey was distributed electronically to health-care professionals (physicians, nurses, etc.) working in various medical facilities such as university hospitals, Ministry of Health affiliated general hospitals, and private hospitals in Egypt during the COVID-19 pandemic.

We targeted two different groups of health-care professionals; the first group were those residing in quarantine hospitals continuously for 14 days with direct contact with COVID-19 patients. The second group consisted of health-care professionals working in non-quarantine hospitals with no routine exposure to COVID-19 patients.

A snowball sampling technique was utilized for the quarantine hospital group due to the hospitals' isolation nature, with no available access to health-care professionals. A convenience sampling technique was utilized for recruiting the non-quarantine group, since it was contacted by disseminating the electronic survey through social media.

\section{Data collection}

A personalized invitation with an online survey link to join the study was sent through email and WhatsApp to health-care professionals, either through the quarantine hospitals' administrators, or directly to the health-care professionals in non-quarantine hospitals through social media.

The survey was self-administered in Arabic and was created using a secured survey platform, to be completed by eligible participants. The survey was strictly anonymous and informed consent was obtained from participants before starting the survey. We used a one-time questionnaire and participants would not be able to re-fill it. Collected data were password-protected and saved to a secured research drive available only to research staff.

Data collected included: 1) Sociodemographic and health information included age, sex, education, marital status, years of experience, residential location, employment status, smoking status, and history of chronic medical conditions; 2) Perceived health over the previous 14 days, rated by one scale (in Short Form-12), which is a valid and reliable scale in Arabic (10); 3) Perceived healthy lifestyle assessed using three questions regarding dietary habits, sufficient rest and sleep during the work period; 4) the Insomnia Severity Index (ISI) - a widely used scale that evaluates insomnia over the previous 14 days $(11,12)$. The Arabic ISI used in this study demonstrated satisfactory validity and reliability, Cronbach's alpha coefficient
$=0.84(13) ; 5)$ Depression, Anxiety, and Stress Scale (DASS21) to evaluate psychological symptoms (14); 6) Worries and concerns about COVID-19 were assessed using four items with a response Likert scale: 'not at all,' 'sometimes,' 'most of the time' and 'all the time'. An additional question was used to assess health-care professionals' readiness to work in quarantine hospitals; 7) Future perspective of health-care professionals about COVID-19 in Egypt was assessed using six items with a response Likert scale: 'strongly agree,' 'agree,' 'disagree,' and 'strongly disagree'; and 8) Coping strategies that health-care professionals in Egypt applied to mitigate anxiety were assessed using an open-ended question that asked to report the strategy demonstrated.

\section{Statistical analysis}

Statistical analysis was done using the Statistical Package for the Social Sciences (SPSS) version 20 (IBM SPSS Statistics, New York, United States of America). Descriptive analysis was performed to present summary statistics for the sociodemographic data, physical health variables, perceived general health, ISI, and DASS-21. Student $t$-test was used to assess the statistical significance of the difference between the two groups' means. A Chi-Square test was used to examine the statistical associations between qualitative variables. Fisher's exact test was used to examine the statistical associations between qualitative variables when the expected count is less than five in more than $20 \%$ of cells. Multivariable logistic regression analysis was used to determine the significant independent predictors of stress, depression and anxiety based on a set of independent variables (age, sex, education, marital status, number of years of experience, readiness to work in quarantine hospitals, having enough rest and sleep, eating healthy and insomnia). The adjusted odds ratio (ORa) and 95\% confidence interval were calculated. All tests were two-tailed, with a significance level of $P<0.05$.

\section{Ethical considerations}

Ethical approval was obtained from the Research Ethics Committee, Faculty of Medicine, Helwan University (no. 23-2020). The confidentiality of the participants' information and workplace (hospitals) was maintained by assigning a unique identification code.

\section{Results}

\section{Sociodemographic and health information}

A total number of 540 respondents from 21 governates in Egypt completed the electronic survey (Table 1); their ages ranged from 20 to 70 years, with a mean of $37.3(S D=9.2)$. The majority were male $(54.4 \%, n=294)$, highly educated (postgraduate) $(78.3 \%, n=423)$, physicians $(77 \%, n=416)$, married $(74.1 \%, n=400)$, had experience of five years or more $(77.8 \%, n=420)$, and a tenth $(10.2 \%, n=55)$ of healthcare professionals were working in quarantine hospitals. 


\begin{tabular}{|c|c|c|c|c|c|c|c|}
\hline \multirow[t]{2}{*}{ Demographic data } & \multirow[b]{2}{*}{$\mathbf{N}$} & \multirow[b]{2}{*}{$\%$} & \multicolumn{2}{|c|}{$\begin{array}{l}\text { Quarantine Hospital } \\
\qquad(N=55)\end{array}$} & \multicolumn{2}{|c|}{$\begin{array}{c}\text { Non-Quarantine } \\
\text { Hospital } \\
(N=485)\end{array}$} & \multirow[t]{2}{*}{$\begin{array}{l}\text { Test value } \\
\text { (P-value) }\end{array}$} \\
\hline & & & $\mathbf{N}$ & $\%$ & $\mathbf{N}$ & $\%$ & \\
\hline Age & \multicolumn{2}{|c|}{$\begin{array}{l}\text { Mean } \pm \text { SD }(37.3-9.2) \\
\text { Range }(20-70)\end{array}$} & \multicolumn{2}{|c|}{$34.4 \pm 8.6$} & \multicolumn{2}{|c|}{$37.6 \pm 9.2$} & $-2.52(0.012)$ \\
\hline \multicolumn{8}{|l|}{ Sex } \\
\hline Female & 246 & 45.6 & 22 & 40.0 & 224 & 46.2 & \multirow{2}{*}{$0.76(0.383)$} \\
\hline Male & 294 & 54.4 & 33 & 60.0 & 261 & 53.8 & \\
\hline \multicolumn{8}{|l|}{ Education } \\
\hline Diploma (after prep) & 6 & 1.1 & 1 & 1.8 & 5 & 1.0 & \multirow{4}{*}{$8.31(0.030)$} \\
\hline Diploma (after secondary education) & 18 & 3.3 & 3 & 5.5 & 15 & 3.1 & \\
\hline University & 93 & 17.2 & 16 & 29.1 & 77 & 15.9 & \\
\hline Postgraduate & 423 & 78.3 & 35 & 63.6 & 388 & 80.0 & \\
\hline \multicolumn{8}{|l|}{ Marital status } \\
\hline Single & 121 & 22.4 & 25 & 45.5 & 96 & 19.8 & \multirow{5}{*}{$16.18(0.002)$} \\
\hline Married & 400 & 74.1 & 29 & 52.7 & 371 & 76.5 & \\
\hline Divorced & 10 & 1.9 & 1 & 1.8 & 9 & 1.9 & \\
\hline Widow & 4 & 0.7 & 0 & 0.0 & 4 & 0.8 & \\
\hline Did not tell & 5 & 0.9 & 0 & 0.0 & 5 & 1.0 & \\
\hline \multicolumn{8}{|l|}{ Occupation } \\
\hline Physician & 416 & 77.0 & 45 & 81.8 & 371 & 76.5 & \multirow{6}{*}{$3.06(0.642)$} \\
\hline Nursing & 49 & 9.1 & 5 & 9.1 & 44 & 9.1 & \\
\hline Pharmacist & 38 & 7.0 & 1 & 1.8 & 37 & 7.6 & \\
\hline House officer & 12 & 2.2 & 1 & 1.8 & 11 & 2.3 & \\
\hline Technician & 9 & 1.7 & 1 & 1.8 & 8 & 1.6 & \\
\hline Other & 16 & 3.0 & 2 & 3.6 & 14 & 2.9 & \\
\hline \multicolumn{8}{|l|}{ Years of experience } \\
\hline$<$ one year & 27 & 5.0 & 3 & 5.5 & 24 & 4.9 & \multirow{5}{*}{$15.08(0.005)$} \\
\hline $1-5$ year & 93 & 17.2 & 19 & 34.5 & 74 & $15 \cdot 3$ & \\
\hline 5-10 years & 114 & 21.1 & 12 & 21.8 & 102 & 21.0 & \\
\hline 10-15 years & 115 & 21.3 & 10 & 18.2 & 105 & 21.6 & \\
\hline$>15$ years & 191 & 35.4 & 11 & 20.0 & 180 & 37.1 & \\
\hline \multicolumn{8}{|l|}{ Smoking } \\
\hline No & 485 & 89.8 & 47 & 85.5 & 438 & 90.3 & \multirow{2}{*}{$1.27(0.259)$} \\
\hline Yes & 55 & 10.2 & 8 & 14.5 & 47 & 9.7 & \\
\hline \multicolumn{8}{|l|}{ Chronic illness } \\
\hline No & 418 & 77.4 & 45 & 81.8 & 373 & 76.9 & \multirow{2}{*}{$0.68(0.409)$} \\
\hline Yes & 122 & 22.6 & 10 & 18.2 & 112 & 23.1 & \\
\hline \multicolumn{8}{|l|}{ Current workplace } \\
\hline Quarantine Hospital & 55 & 10.2 & - & - & - & - & Not Applicable \\
\hline Non-Quarantine Hospital & 485 & 89.8 & - & - & - & - & (19) \\
\hline Type of hospitals & & & & & & & \\
\hline University Hospital & 266 & 49.3 & - & - & - & - & - \\
\hline General Hospital & 145 & 26.9 & - & - & - & - & - \\
\hline $\begin{array}{l}\text { Other hospitals (i.e. Private hospitals, } \\
\text { centers,...etc...) }\end{array}$ & 129 & 239 & - & - & - & - & - \\
\hline
\end{tabular}




\begin{tabular}{|c|c|c|c|c|c|c|c|}
\hline \multirow[t]{2}{*}{ Demographic data } & \multirow[b]{2}{*}{$\mathbf{N}$} & \multirow[b]{2}{*}{$\%$} & \multicolumn{2}{|c|}{$\begin{array}{l}\text { Quarantine Hospital } \\
\qquad(N=55)\end{array}$} & \multicolumn{2}{|c|}{$\begin{array}{c}\text { Non-Quarantine } \\
\text { Hospital } \\
(\mathbf{N}=485)\end{array}$} & \multirow[t]{2}{*}{$\begin{array}{l}\text { Test value } \\
\text { (P-value) }\end{array}$} \\
\hline & & & $\mathbf{N}$ & $\%$ & $\mathbf{N}$ & $\%$ & \\
\hline \multicolumn{8}{|l|}{ Governorates } \\
\hline Giza & 63 & 11.6 & - & - & - & - & \multirow{9}{*}{ Not Applicable } \\
\hline Cairo & 207 & 38.3 & - & - & - & - & \\
\hline Alex & 34 & 6.3 & - & - & - & - & \\
\hline Dumiata & 59 & 10.9 & - & - & - & - & \\
\hline Assuit & 34 & 6.3 & - & - & - & - & \\
\hline Sharqia & 24 & 4.4 & - & - & - & - & \\
\hline Gharbia & 17 & 3.1 & - & - & - & - & \\
\hline Kafr el sheikh & 9 & 1.7 & - & - & - & - & \\
\hline Other & 93 & 17.2 & - & - & - & - & \\
\hline
\end{tabular}

\section{Perceived general health and healthy lifestyle}

Regarding perceived general health status, the majority (94.6\%, $n=511$ ) of the respondents described their health as very good $(26.6 \%, n=144)$, good $(25.0 \%, n=135)$ or the same $(43.0 \%, n=232)$; the remainder rated their health as worse $(5.0 \%, n=27)$ or much worse $(0.4 \%, n=2)$. Regarding readiness to work in quarantine hospitals, approximately a quarter of respondents $(N=540)$ said they were ready $(27.8 \%, n=150)$. Perceived general health was insignificant between quarantine and non-quarantine group ( $t=8.15$, $P=0.076)$.

Health-care professionals' response $(n=540)$ to questions regarding healthy lifestyle is presented in Figure 1. Quarantine group and non-quarantine group participants had significant differences in receiving enough rest and eating healthily during the working

\section{Figure 1 Healthy lifestyle}

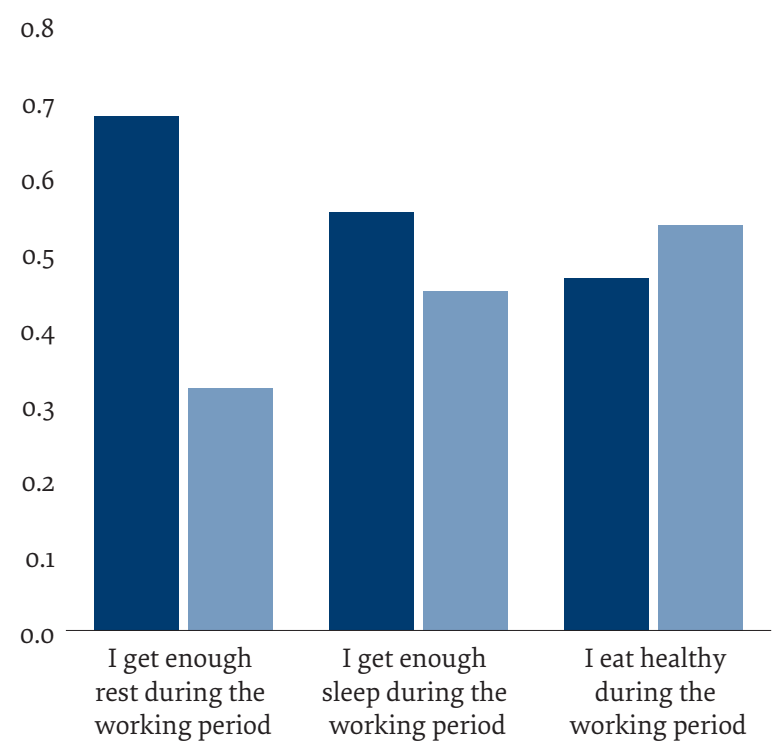

Yes No period ( $t=4.08 P=0.044, t=7.24 P=0.007$, respectively). However, there was an insignificant difference regarding receiving enough sleep during the working period.

\section{Psychological symptoms and insomnia}

Over one half of the respondents reported some form of adverse psychological symptom as follows: mild to severe stress $(37.2 \%, n=201)$, depression $(59.0 \%, n=319)$, and anxiety $(42.6 \%, n=230)$. Just over one half of respondents (51.9\%, $n=280$ ) reported sub-threshold insomnia to severe insomnia. The quarantine group and the non-quarantine group had an insignificant difference in adverse psychological symptoms and insomnia (Table 2).

\section{Factors associated with perceived psychological symptoms using bivariate analysis}

Our results show that participants who were of a young age, female, married, and with less than 1 year of work experience were more likely to experience stress, depression, and anxiety $(P<0.001)$. Participants educated to university and postgraduate level were also more likely to experience stress and depression.

Insomnia was high among those who reported experiencing stress, depression and anxiety $(P<0.001)$. Respondents who reported 'yes' to working in quarantine hospitals were more likely to have lower adverse psychological symptoms than respondents who said 'no' or 'not sure' $(P<0.001)$. Additionally, respondents who did not receive enough rest, sleep, or healthy food during their working period were more likely to report adverse psychological symptoms (stress, depression and anxiety) $(P<0.01)$. Participants having low perceived general health and worries over the risk of transmission of COVID to families were more likely to experience stress, depression and anxiety, among whom panic attacks were not uncommon and an avoidance of the workplace due to fear of infection $(P<0.001)$.

Table 3 displays the multivariable logistic regression analysis to determine predictors of stress, depression 


\begin{tabular}{|c|c|c|c|c|c|c|}
\hline & \multicolumn{2}{|c|}{ Stress } & \multicolumn{2}{|c|}{ Depression } & \multicolumn{2}{|c|}{ Anxiety } \\
\hline & $\%$ & $\boldsymbol{N}$ & $\%$ & $\boldsymbol{N}$ & $\%$ & \\
\hline \multicolumn{7}{|l|}{ DASS-21 } \\
\hline Normal & 339 & 62.8 & 221 & 40.9 & 310 & 57.4 \\
\hline Mild & 66 & 12.2 & 93 & 17.2 & 87 & 16.1 \\
\hline Moderate & 53 & 9.8 & 122 & 22.6 & 62 & 11.5 \\
\hline Severe & 61 & 11.3 & 53 & 9.8 & 30 & 5.6 \\
\hline Extremely severe & 21 & 3.9 & 51 & 9.4 & 51 & 9.4 \\
\hline Mean \pm SD & \multicolumn{2}{|c|}{$7.0 \pm 4.6$} & \multicolumn{2}{|c|}{$6.4 \pm 4.6$} & \multicolumn{2}{|c|}{$3.8 \pm 3.6$} \\
\hline Range & \multicolumn{2}{|c|}{$0-21$} & \multicolumn{2}{|c|}{$0-21$} & \multicolumn{2}{|c|}{$0-18$} \\
\hline \multicolumn{7}{|c|}{$\begin{array}{l}\text { Quarantine Hospital }(N=55) \text { vs. } \\
\text { Non-Quarantine Hospital }(N=485) \\
\text { Test value ( } p \text {-value) }\end{array}$} \\
\hline \multicolumn{7}{|l|}{ Insomnia-scale } \\
\hline No insomnia & & & & & - & - \\
\hline Subthreshold insomnia & & & & & - & - \\
\hline Moderate insomnia & & & & & - & - \\
\hline Severe insomnia & & & & & - & - \\
\hline Mean \pm SD & \multicolumn{4}{|c|}{$8.9 \pm 6.4$} & \multicolumn{2}{|c|}{-} \\
\hline Range & \multicolumn{4}{|c|}{$0-28$} & \multicolumn{2}{|c|}{-} \\
\hline \multicolumn{7}{|c|}{$\begin{array}{l}\text { Quarantine Hospital }(N=55) \text { vs. } \\
\text { Non-Quarantine Hospital }(N=485)\end{array}$} \\
\hline
\end{tabular}

and anxiety among health-care professionals ( $n=540)$. Younger age (ORa=0.96, 95\% CI: 0.93-0.99), female gender (ORa $=1.59,95 \% \mathrm{CI}: 1.04-2.42$ ), being 'not ready' or 'not sure of readiness' to work in a quarantine hospital (ORa=1.91, 95\% CI: 1.22-3.00), university or postgraduate education $(\mathrm{ORa}=5.19,95 \% \mathrm{CI}: 1.36-19.79)$, and insomnia $(\mathrm{ORa}=5.22$, 95\% CI: 3.38-8.05) could significantly predict stress. Younger age $(\mathrm{ORa}=0.95,95 \% \mathrm{CI}$ : 0.92-0.97), being 'not ready' or 'not sure of readiness to work' in a quarantine hospital (ORa=2.01, 95\% CI: 1.28-3.15) and insomnia (ORa $=7.58,95 \%$ CI: 4.91-11.68) could significantly predict depression. Younger age (ORa $=0.96, C I: 0.93-0.99)$, female gender $(\mathrm{ORa}=2.09,95 \% \mathrm{CI}$ : 1.38-3.16), being 'not ready' or 'not sure of readiness to work' in a quarantine hospital (ORa $=1.91,95 \%$ CI: 1.22-2.98) and insomnia (ORa=6.38 95\% CI: 4.19-9.73) could significantly predict anxiety.

\section{Experiencing worry about COVID-19}

Table 4 indicates that $97.0 \%$ of health-care professionals $(n=524)$ experienced feelings of worry over transmitting COVID-19 to their families; $72.0 \%(n=389)$ had experi-

\begin{tabular}{|c|c|c|c|c|c|c|}
\hline \multirow[t]{2}{*}{ Variables } & \multicolumn{2}{|c|}{ Stress } & \multicolumn{2}{|c|}{ Depression } & \multirow{2}{*}{$\begin{array}{c}\text { Anxiety } \\
\text { (ORa) }(95 \% \mathrm{CI})\end{array}$} & \multirow{2}{*}{$P$ value } \\
\hline & (ORa) $(95 \% \mathrm{CI})$ & $P$ value & (ORa) $(95 \%$ CI) & P value & & \\
\hline Age & $0.96(0.93-0.99)$ & 0.003 & $0.95(0.92-0.97)$ & $<0.001$ & $0.96(0.93-0.99)$ & 0.003 \\
\hline Sex (female) & $1.59(1.04-2.42)$ & 0.032 & $1.49(0.97-2.3)$ & 0.072 & $2.09(1.38-3.16)$ & 0.001 \\
\hline University or postgraduate education & $5.19(1.36-19.79)$ & 0.016 & $2.00(0.72-5.56)$ & 0.182 & $1.03(0.37-2.87)$ & 0.957 \\
\hline Marital status (single) & $1.13(0.66-1.95)$ & 0.660 & $1.38(0.77-2.47)$ & 0.274 & $1.11(0.65-1.91)$ & 0.704 \\
\hline Number of years of experience ( $<1$ year) & $1.23(0.42-3.55)$ & 0.704 & $1.71(0.46-6.39)$ & 0.428 & $0.69(0.25-1.91)$ & 0.470 \\
\hline $\begin{array}{l}\text { Not sure or not Ready to work in } \\
\text { quarantine hospital }\end{array}$ & $1.91(1.22-3.00)$ & 0.005 & $2.01(1.28-3.15)$ & 0.002 & $1.91(1.22-2.98)$ & 0.004 \\
\hline Not enough rest & $1.53(0.89-2.62)$ & 0.122 & $1.33(0.74-2.38)$ & 0.335 & $0.98(0.57-1.69)$ & 0.932 \\
\hline Not enough sleep & $1.58(0.93-2.68)$ & 0.092 & $1.03(0.58-1.81)$ & 0.919 & $1.73(1.01-2.95)$ & 0.047 \\
\hline Not eating healthy & $1.05(0.66-1.67)$ & 0.834 & $1.20(0.75-1.91)$ & 0.443 & $0.91(0.58-1.44)$ & 0.690 \\
\hline Insomnia & $5.22(3.38-8.05)$ & $<0.001$ & $7.58(4.91-11.68)$ & $<0.001$ & $6.38(4.19-9.73)$ & $<0.001$ \\
\hline
\end{tabular}




\begin{tabular}{|c|c|c|c|c|c|}
\hline Worries and concerns about COVID-19 & & Not at all & Sometimes & most of the time & all the time \\
\hline$N=540$ & & $\mathbf{N}(\%)^{*}$ & $N(\%)^{*}$ & $\mathbf{N}(\%)^{*}$ & $N(\%)^{*}$ \\
\hline 1. I feel worried to transmit COVID to my family & & $16(3.0)$ & $124(2.0 \%)$ & $174(32.2)$ & $226(41.9)$ \\
\hline $\begin{array}{l}\text { 2. One of my colleagues had a panic attack } \\
\text { recently }\end{array}$ & & $94(17.4)$ & $212(39.3)$ & $172(31.9)$ & $62(11.5)$ \\
\hline 3. I had a panic attack recently & & $151(28.0)$ & $228(42.2)$ & $106(19.6)$ & $55(10.2)$ \\
\hline $\begin{array}{l}\text { 4. I think of apologizing to work due to fear of } \\
\text { infection }\end{array}$ & & $275(50.9)$ & $146(27.0)$ & $67(12.4)$ & $52(9.6)$ \\
\hline Future perspective & Strongly agree & Agree & Disagree & Strongly disagree & Don't know \\
\hline$N=540$ & $N(\%)^{*}$ & $N(\%)^{*}$ & $N(\%)^{*}$ & $N(\%)^{*}$ & $N(\%)^{*}$ \\
\hline $\begin{array}{l}\text { 1. COVID is still under control in Egypt } \\
\text { compared to other countries }\end{array}$ & $50(9.3)$ & $279(51.7)$ & $130(24.1)$ & $41(7.6)$ & $40(7.4)$ \\
\hline $\begin{array}{l}\text { 2. COVID is less prevalent in Egypt due to high } \\
\text { temperature }\end{array}$ & $11(2.0)$ & $97(17.9)$ & $239(44.3)$ & $78(14.4)$ & $115(21.3)$ \\
\hline $\begin{array}{l}\text { 3. COVID is less prevalent in Egypt due to high } \\
\text { humidity }\end{array}$ & $7(1.3)$ & $43(7.9)$ & $265(49.1)$ & $85(15.7)$ & $140(25.9)$ \\
\hline $\begin{array}{l}\text { 4. Herd immunity strategy can decrease the } \\
\text { prevalence of COVID in Egypt }\end{array}$ & $33(6.1)$ & $176(32.6)$ & $153(28.3)$ & $71(13.2)$ & $107(19.8)$ \\
\hline 5. Egypt can control COVID & $29(5.4)$ & $193(35.7)$ & $139(25.7)$ & $56(10.4)$ & $123(22.8)$ \\
\hline $\begin{array}{l}\text { 6. I am worried that the virus might become } \\
\text { more virulent and cannot be controlled }\end{array}$ & $155(28.7)$ & $278(51.5)$ & $66(12.2)$ & $16(2.9)$ & $25(4.6)$ \\
\hline Coping strategies with anxiety & \multicolumn{2}{|c|}{$N=540$} & \multicolumn{3}{|c|}{$\%$} \\
\hline 5. Reading & \multicolumn{2}{|c|}{29} & \multicolumn{3}{|c|}{5.4} \\
\hline 6. Listening/ reading Quran & \multicolumn{2}{|c|}{108} & \multicolumn{3}{|c|}{20.0} \\
\hline 7. Listening to music & \multicolumn{2}{|c|}{11} & \multicolumn{3}{|c|}{2.0} \\
\hline 8. Exercises & \multicolumn{2}{|c|}{15} & \multicolumn{3}{|c|}{2.8} \\
\hline 9. Taking to others & \multicolumn{2}{|c|}{105} & \multicolumn{3}{|c|}{19.4} \\
\hline $\begin{array}{l}\text { 10. Mix coping strategies (listening to religious } \\
\text { talks, music, reading, talking to others, } \\
\text { exercises, watching TV) }\end{array}$ & \multicolumn{2}{|c|}{272} & \multicolumn{3}{|c|}{50.4} \\
\hline
\end{tabular}

${ }^{*}$ Row percentage

enced a recent panic attack; $82.6 \%(n=446)$ knew a colleague who had a recent panic attack, and 49.1\% $(n=265)$ considered avoiding the workplace due to fear of infection.

\section{Respondents' perspective and anxiety-coping strategies}

Most respondents considered COVID-19 infection to be under control in Egypt when compared to other countries (60.9\%, $n=329$ agree), and that Egypt will control COVID-19 in the future (41.1\%, $n=222$ agree). However, the majority were worried that the virus might become more virulent and control could be lost $(80.2 \%, n=433$ agree). Most respondents disagreed with high temperature $(58.7 \%, n=317$ disagree), high humidity $(64.8 \%, n=350$ disagree), or that a herd immunity strategy (41.5\%, $n=224$ disagree) could decrease the prevalence of COVID-19 in Egypt.

More than half of health-care professionals in this study used mixed coping strategies to overcome their anxiety feeling; primarily religious and social interaction (Table 4).

\section{Discussion}

To the best of our knowledge this is the first Egyptian study to evaluate the mental health status of health-care professionals in Egypt during the COVID-19 pandemic working in quarantine and non-quarantine hospitals.

\section{Adverse psychological symptoms and insomnia}

Our study revealed that adverse psychological symptoms (stress, depression and anxiety) had been recorded in almost one third to one half of respondents, while insomnia had been recorded in more than half. Similar results were found in other studies addressing psychological outcomes in health-care professionals $(15,16)$. The majority of health-care professionals considered the COVID-19 pandemic to be under control in Egypt. However, a majority also believed that this control of the situation was fragile and could easily deteriorate, which could reflect the prevalence of worry reported by respondents.

The lack of significant statistical differences between the quarantine and non-quarantine groups with regard to adverse psychological symptoms and insomnia could be attributed to accessing the same information sources about the pandemic. Indeed, the COVID-19 situation 
was shown to have a negative impact on individuals' psychological, social and economic status, as well as longterm consequences for the community overall, regardless of sociodemographic background (17).

\section{Associated factors}

Psychological preparation and support for health care professionals requires thorough investigation and preparation, similar to what took place in China (18). Using the regression analysis, we can conclude that younger age, being 'not ready' or 'unsure of readiness to work' in a quarantine hospital, and having insomnia could significantly predict stress, depression and anxiety. Female gender could also significantly predict experiences of stress and anxiety when compared to males in the groups. Similarly, previous studies among health-care professionals have indicated that females are at a higher risk of developing anxiety and depression in such situations $(16,19)$.

Our study showed that younger health-care professionals were more likely to report stress, depression and anxiety compared to older health-care professionals. Previous studies have acknowledged that older age indicated better coping mechanisms for anxiety (20), while younger age was indicative of higher levels of psychological morbidities (21). Accordingly, sufficient years of experience might act as an effective buffer against adverse psychological effects of working in a stressful situation. However, in our study psychological well-being was not necessarily correlated with participants' years of experience.

Respondents who reported 'yes' to working in quarantine hospitals were more likely to have lower adverse psychological symptoms than respondents who said 'no' or 'not sure'. Insomnia was high among those who reported experiencing stress, depression and anxiety. Respondents who did not receive enough rest, sleep or healthy food during their working period were more likely to report adverse psychological symptoms (stress, depression and anxiety). Similarly, previous studies have shown that sleep quality could predict adverse psychological symptoms in health care professionals (22). In addition, absence of any definitive COVID-19 treatment or vaccine, lack of evidence about the effectiveness of a herd immunity strategy, the existence of more than one genotype of COVID-19, and expectation of a new wave of infections, can reflect negatively on health care professionals' psychological well-being $(17,23)$.

More than half of study participants reported using mixed coping strategies for anxiety, such as religious discussion, listening to music, reading, social interaction, physical exercise, etc. Education level did not show a statistically significant difference in developing anxiety, which was similar to findings by Chua et al. during the SARS epidemic (24). However, being educated was correlated with higher levels of depression and stress, although this would appear to contradict most previous findings of the relation between education and depression (23-26).

\section{Health and lifestyle}

Receiving enough sleep and rest during working hours was associated with less lower levels of stress, depression or anxiety. This supports the importance of scheduling enough time for rest for health care professionals to avoid burn out. The same was noted for healthy food and its association with better psychological performance and emphasizes the importance of psychological support not only for patients, but also for those working in health institutions. (20).

Fear of COVID-19 transmittance to family members, and subsequently avoidance of working in quarantine hospitals, was widespread in health-care professionals, with statistical significance indicated for the development of depression, anxiety and stress. This could be attributed to the presumption that protective measures might be lacking and the relative shortage in personal protective equipment such as face masks, face shields, lack of community surveillance, and support for the herd immunity strategy.

\section{Limitations}

The current study has a number of limitations. Cross-sectional self-reported data might be susceptible to over or underestimation by participants, and an inability to develop a causal relationship between the studied variables. Accessing health-care professionals in quarantine hospitals was problematic; therefore, the relatively small sample size could be attributed to the limited number of available health-care professionals dealing with COVID-19. Repeating this study on a large sample of healthcare professionals working in quarantine hospitals using a longitudinal research design is highly recommended.

\section{Conclusion}

The COVID-19 pandemic is a global event that significantly affects the social and psychological well-being of health care professionals, whether working in quarantine or non-quarantine hospitals. Being female, younger age, experiencing insomnia, and not having 'readiness to work' in quarantine hospitals indicated a higher correlation with adverse psychological symptoms. Sufficient psychological support for health-care professionals is required, as well as adequate sleep and rest during working hours. Therefore, evaluating health-care professionals' readiness to work with COVID-19 patients is recommended for identifying any at-risk individuals. Accordingly, the involvement of more experienced health-care professionals in COVID-19 management should be a consideration. The Egyptian government needs to devote more attention to community-based campaigns for screening and early detection of infected cases. However, that will not be achieved without sufficient and well-established laboratory infrastructures in all regions $(27,28)$.

Funding: None.

Competing interests: None declared. 


\section{État de santé mentale des professionnels de santé travaillant dans les hôpitaux égyptiens dédiés ou non à la quarantaine pendant la pandémie de COVID-19 RÉSUMÉ}

Contexte : Des modèles de soins variables ont été adoptés dans différents pays pour riposter à la pandémie de COVID-19. L'Égypte a affecté certains hôpitaux spécifiquement à la quarantaine des patients atteints de COVID-19, où les membres des équipes médicales opérationnelles travaillent en continu pendant 14 jours, après quoi ils sont libérés pour s'isoler à domicile pendant une période similaire.

Objectifs : L'étude visait à évaluer et à comparer les symptômes psychologiques perçus (stress, anxiété, dépression) et l'insomnie par les professionnels de santé travaillant dans des hôpitaux dédiés ou non à la quarantaine pendant la pandémie de COVID-19 en Égypte, et à examiner les facteurs associés aux symptômes psychologiques et à l'insomnie.

Méthodes : Une enquête transversale a été réalisée en ligne en avril 2020, en recourant à un échantillonnage boule de neige. Des données sociodémographiques, des informations concernant la santé générale perçue, un mode de vie sain, l'insomnie (au moyen de l'indice de gravité de l'insomnie), les symptômes psychologiques (au moyen de l'échelle Depression, Anxiety and Stress Scale-21), les inquiétudes et les préoccupations à propos de la COVID-19, la perspective future vis-à-vis de la COVID-19 et les stratégies d'adaptation ont été recueillies.

Résultats : Cinq cent quarante professionnels de santé ont participé à l'étude ; 10,2\% ( $n=55)$ travaillaient dans des hôpitaux dédiés à la quarantaine. Le jeune âge (ORa=0,96, IC à $95 \%: 0,93-0,99, \mathrm{ORa}=0,95, \mathrm{IC}$ à $95 \%$ : 0,92-0,97; $\mathrm{ORa}=0,96$, IC à $95 \%: 0,93-0,99)$, le fait de ne pas être prêt/certain de pouvoir travailler dans un hôpital dédié à la quarantaine (ORa=1,91, IC à $95 \%: 1,22-3,00 ; \mathrm{ORa}=2,01$, IC à $95 \%: 1,28-3,15 ; \mathrm{ORa}=1,91, \mathrm{IC}$ à $95 \%: 1,22-2,98)$ et l'insomnie (ORa=5,22, IC à $95 \%: 3,38-8,05 ; \mathrm{ORa}=7,58$, IC à $95 \%: 4,91-11,68$; ORa=6,38, IC à 95\%:4,19-9,73) ont permis de prédire de manière significative le stress, la dépression et l'anxiété, respectivement. L'appartenance au sexe féminin $(\mathrm{ORa}=1,59$, IC à $95 \%: 1,04-2,42$; ORa=2,09, IC à $95 \%: 1,38-3,16)$ pourrait également prédire de manière significative le stress et l'anxiété.

Conclusions : Les professionnels de santé de sexe féminin et plus jeunes étaient plus enclins à signaler des symptômes psychologiques. Un dépistage plus précoce et plus poussé des professionnels de santé confrontés à la COVID-19 ainsi qu'un soutien psychologique, sont vivement encouragés.

$$
\text { نجائحة كوفيد الصحة النفسية للمهنيين في ججال الرعاية الصحية العاملين في مستشفيات الحجر الصحي وغيرها في مصر أثناء }
$$

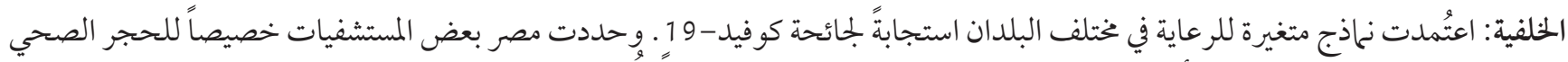

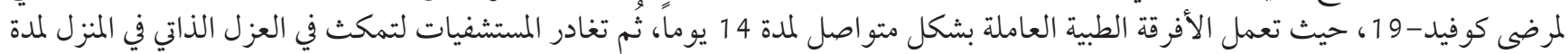

الأهداف: كانت الدراسة تهدف إلى تقييم الأعر اض النفسية المتصورة ومقارنتها (الإجهاد، و القلق، و الاكتئاب)، و الأرق الذي يعاني منه المهنيون

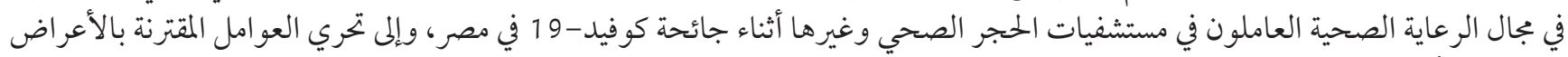
طرق البحتة و الأرق.

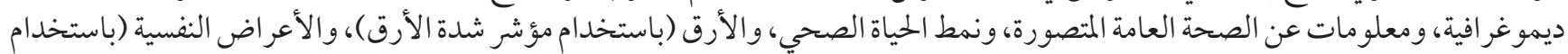

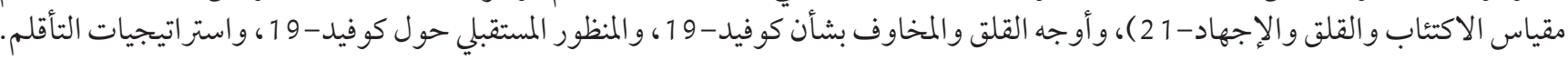

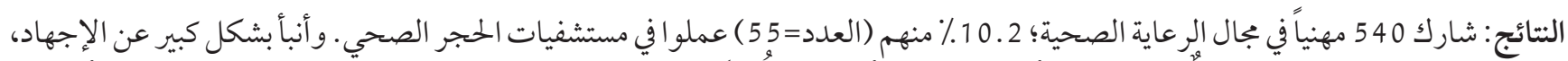

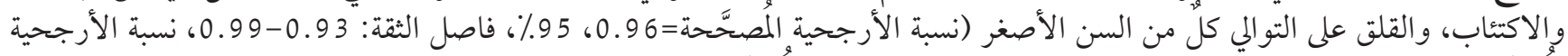

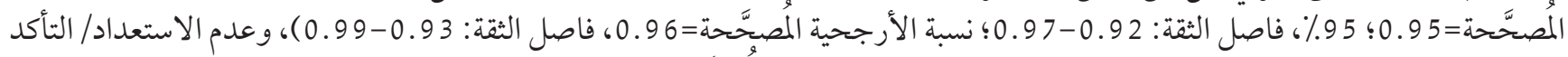

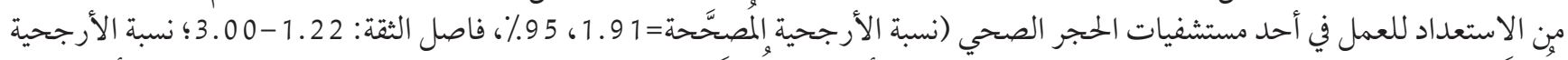
المصحَّحة=1 2.0 2.

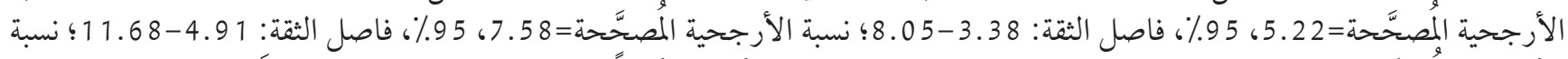

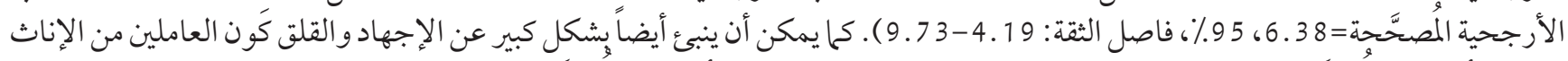

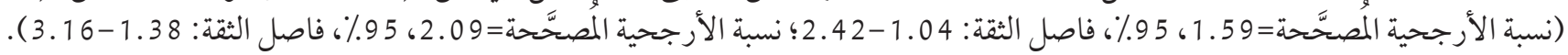




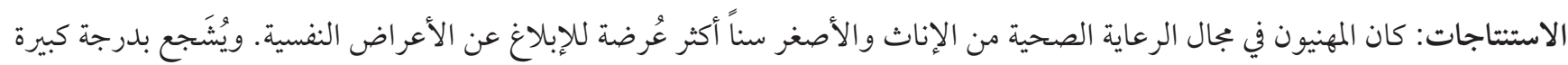

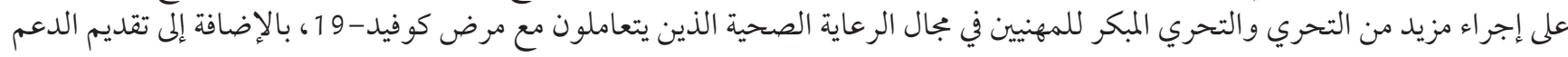
النفسي لمم.

\section{References}

1. Li Q, Guan X, Wu P, Wang X, Zhou L, Tong Y, et al. Early transmission dynamics in Wuhan, China, of novel coronavirus-infected pneumonia. N Engl J Med. 2020;382(13):1199-1207. doi:10.1056/NEJMoa2001316

2. World Health Organization. 2020A. Report of the WHO-China joint mission on coronavirus disease 2019 (COVID-19). Geneva: World Health Organization; 2020. (https://www.who.int/docs/defaultsource/coronaviruse/who-china-joint-mission-on-covid-19final-report.pdf).

3. Mowafi H, Sakr H, Ravaghi H, Elmahal O, Slama S, Samhouri D, et al. Leveraging the COVID-19 response to improve emergency care systems in the Eastern Mediterranean Region. East Mediterr Health J. 2020;26(6):626-629. https://doi. org/10.26719/2020.26.6.626.

4. El-Awa F, Fraser CP, Adib K, Hammerich A, Abdel Latif N, Fayokun R, et al. The necessity of continuing to ban tobacco use in public places post-COVID-19. East Mediterr Health J. 2020;26(6):630-632. https://doi.org/10.26719/emhj.20.071.

5. Lai J, Ma S, Wang Y, Cai Z, Hu J, Wei N, et al. Factors associated with mental health outcomes among health care workers exposed to coronavirus disease 2019. JAMA Netw Open. 2020;3(3):e203976. doi:10.1001/jamanetworkopen.2020.3976.

6. Ran L, Chen X, Wang Y, Wu W, Zhang L, Tan X. Risk factors of healthcare workers with corona virus disease 2019: A retrospective cohort study in a designated hospital of Wuhan in China [published online ahead of print, 2020 Mar 17]. Clin Infect Dis. 2020;ciaa287. doi:10.1093/cid/ciaa287.

7. National Center for Posttraumatic Stress Disorder (PTSD). Managing healthcare workers' stress associated with the COVID-19 virus outbreak. https://www.ptsd.va.gov/covid/COVID_healthcare_workers.asp, accessed 2 May, 2020).

8. Ho CS, Chee CY, Ho RC. Mental health strategies to combat the psychological impact of COVID-19 beyond paranoia and panic. Ann Acad Med Singap. 2020;49(3):155-160.

9. Agostini T, Grassi M, Pellizzoni S, Murgia M. The Arabic Impact of Event Scale-Revised: psychometric properties in a sample of Syrian refugees. Horizons of Psychology. In 13th Alps Adria Psychology Conference. 2018;27:86-86.

10. Obtel M, El Rhazi K, Elhold S, Benjelloune M, Gnatiuc L, Nejjari C. Cross-cultural adaptation of the 12-Item Short-Form survey instrument in a Moroccan representative survey. Southern African Journal of Epidemiology and Infection. 2013;28(3):166-171. doi :10.1080/10158782.2013.11441540.

11. Morin CM. Insomnia: psychological assessment and management. Guildford: The Guilford Press; 1996.

12. Bastien $\mathrm{CH}$, Vallières A, Morin CM. Validation of the Insomnia Severity Index as an outcome measure for insomnia research. Sleep Med. 2001;2(4):297-307. doi:10.1016/s1389-9457(00)00065-4.

13. Suleiman KH, Yates BC. Translating the insomnia severity index into Arabic. J Nurs Scholarsh. 2011;43(1):49-53. doi:10.1111/j.15475069.2010.01374.x

14. Moussa MT, Lovibond P, Laube R, Megahead HA. Psychometric properties of an Arabic Version of the Depression Anxiety Stress Scales (DASS). Research on social work practice. 2016;27(3). doi:10.1177/1049731516662916.

15. Chew NWS, Lee GKH, Tan BYQ, Jing M, Goh Y, Ngiam NJH, et al. A multinational, multicentre study on the psychological outcomes and associated physical symptoms amongst healthcare workers during COVID-19 outbreak. Brain Behav Immun. 2020;88:559-565. doi:10.1016/j.bbi.2020.04.049

16. Thapa L, Ghimire A, Ghimire S, Sharma N, Shrestha S, Devkota P, et al. Predictors of anxiety regarding the COVID-19 pandemic among health-care workers in a hospital not assigned to manage COVID-19 patients in Nepal. medRxiv preprint. 2020. doi:10.110 1/2020.07.08.20148866.

17. Rawaf S, Quezada Yamamoto H, Rawaf D. Unlocking towns and cities: COVID-19 exit strategy. East Mediterr Health J. 2020;26(5):499-502. https://doi.org/10.26719/emhj.20.028.

18. Patel A, Jernigan DB. 2019 $\triangle \mathrm{nCoV}$ CDC response team. Initial public health response and interim clinical guidance for the 2019 novel coronavirus outbreak - United States, December 31, 2019 - February 4, 2020. Am J Transplant. 2020;20(3):889-895. doi:10.1111/ajt.15805.

19. Wilson W, Raj JP, Rao S, Ghiya M, Nedungalaparambil NM, Mundra H, et al. Prevalence and predictors of stress, anxiety, and depression among healthcare workers managing COVID-19 pandemic in India: a nationwide observational study. Indian Indian J Psychol Med. 2020;42(4):353-358. doi: 10.1177/0253717620933992.

20. Leung GM, Lam TH, Ho LM, Ho SY, Chan BH, Wong IO, et al. The impact of community psychological responses on outbreak control for severe acute respiratory syndrome in Hong Kong [published correction appears in J Epidemiol Community Health. 2003 Dec;57(12):995]. J Epidemiol Community Health. 2003;57(11):857-863. doi:10.1136/jech.57.11.857.

21. Sim K, Huak Chan Y, Chong PN, Chua HC, Wen Soon S. Psychosocial and coping responses within the community health care setting towards a national outbreak of an infectious disease. J Psychosom Res. 2010;68(2):195-202. doi:10.1016/j.jpsychores.2009.04.004. 
22. Díaz Ramiro EM, Rubio Valdehita S, López Núñez MI, Aparicio García ME. Sleep habits as predictors of psychological health in healthcare professionals. Annals of Psychology, 2020;36(2):242-246

23. Al-Mandhari A, Kodama C, Abubakar A, Brennan R. Solidarity in response to COVID-19 outbreak in the Eastern Mediterranean Region. East Mediterr Health J. 2020;26(5):492-494. https://doi.org/10.26719/2020.26.5.492.

24. Chua SE, Cheung V, Cheung C, McAlonan GM, Wong JW, Cheung EP, et al. Psychological effects of the SARS outbreak in Hong Kong on high-risk health care workers. Can J Psychiatry. 2004;49(6):391-393. doi:10.1177/070674370404900609

25. Ross CE, Mirowsky J. Sex differences in the effect of education on depression: resource multiplication or resource substitution? Soc Sci Med. 2006;63(5):1400-1413. doi:10.1016/j.socscimed.2006.03.013.

26. Ross CE, Mirowsky J. Gender and the health benefits of education. Sociol Q. 2010;51(1):10.1111/j.1533-8525.2009.01164.x. doi:10.1111/ j.1533-8525.2009.01164.x.

27. Konings F, Barakat A, Hutin Y, Hajjeh R. COVID-19 highlights the need for a strong health laboratories foundation for infectious disease surveillance and control in the Eastern Mediterranean Region. East Mediterr Health J. 2020;26(6):633-635. https://doi. org/10.26719/emhj.20.074.

28. Medhat MA, El Kassas M. COVID-19 in Egypt: Uncovered figures or a different situation? J Glob Health. 2020;10(1):010368. doi:10.7189/jogh.10.010368. 